\title{
Mathematical model to optimize drilling-and-blasting operations in the process of open-pit hard rock mining
}

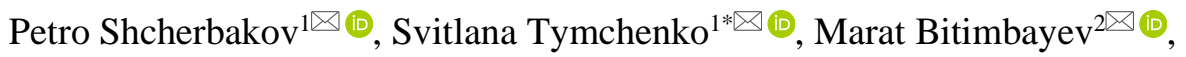 \\ Nurzhigit Sarybayev $^{3 \otimes(D)}$, Serik Moldabayev ${ }^{3 \otimes}$ (D) \\ ${ }^{1}$ Dnipro University of Technology, Dnipro, 49005, Ukraine \\ ${ }^{2}$ National Engineering Academy of Kazakhstan, Almaty, 50010, Kazakhstan \\ ${ }^{3}$ Satbayev University, Almaty, 50013, Kazakhstan \\ *Corresponding author: e-mail tymchenko.s.ye@nmu.one, tel. +380501598976
}

\begin{abstract}
Purpose is to determine a function of the reduced expenditures connected with drilling-and-blasting operations, loading and hauling operations, and rock fragmentation depending upon the cost of machine-shift of the applied facility, its operation modes, hardness of rock being blasted, cost of the used explosive, and rock fragmentation quality based upon the developed optimization mathematical model.

Methods. Method of statistical evaluation of natural blockiness structure of the rock as well as quality of its fragmentation by means of explosive energy has been applied. Statistical studies have been carried out concerning the basic indices of rock fragmentation depending upon its largeness and block hardness. Purposely-designed experimental equipment has been applied for sampling analysis of the rock fracturing in the process of its drilling by means of rotary drilling rig. The abovementioned supported representativeness of the sampling.

Findings. Statistical distributions of the rock blockiness structure in terms of each bar length involving its place within the drilling assembly as well as in terms of the well depth have been compiled. Visual comparison of experimental data and theoretical data has helped determine that the statistical distributions of natural blockiness structure of the rock have the closest correlation with gamma distribution which differential function has two positive parameters. Statistical dependence has been defined between drilling-and-blasting results and the total expenditures connected with hard rock mining.

Originality. A concept of oversize crushing coefficient has been introduced; its statistical dependence upon the mined rock hardness and specific consumption of the applied explosive has been derived. An alternative has been proposed concerning changes in parameters of the differential function of the assumed gamma distribution relative to the predicted granulometric composition of rock mass.

Practical implications. Economic and mathematical model has been developed involving a target function of the total expenditures connected with the listed operations as well as a set of constraints avoiding incorrect decisions. The optimization method makes it possible to control drilling-and-blasting parameters at each stage of hard rock mining.
\end{abstract}

Keywords: open pit, excavator, efficiency, granulometric composition, rock mass

\section{Introduction}

Technological procedure of hard rock extraction by means of surface mining operations involves its preliminary fragmentation with the help of drilling-and-blasting (DB) and further processing of the obtained rock mass [1]-[3]. In this context, the rock mass crushing quality (i.e. its granulometric composition) depends upon the strength of rocks being blasted as well as upon the implemented DB parameters among which well spacing and blasting charge formula are the key ones [2]-[4]. The parameters are used to identify specific consumption of the explosive (E) which value dominates both in calculations and real-world applications. Rock mass crushing quality is evaluated with the help of an average rock diameter and a dominant fraction value, i.e. both mode and modal amount of statistical rock distribution within its known volume [5].

Control methods of DB system, applied under the specific mining and geological conditions, are quite important to determine economic performance of the whole mining cycle [6]. Increase in the specific E consumption factors into more intensive rock mass fragmentation making it possible to reduce costs for its loading, hauling, and fragmentation. However, in this case expenditures connected with execution 
of the whole set of DB operations increase [7]. To the contrary, fragmentation of rock mass using blasting results in opposite changes in expenditures connected with the technological procedures [8]. Hence, such a granulometric rock mass composition is available for each mining and geological condition in terms of which minimum total costs for hard rock are provided for its mining and processing (Fig. 1).

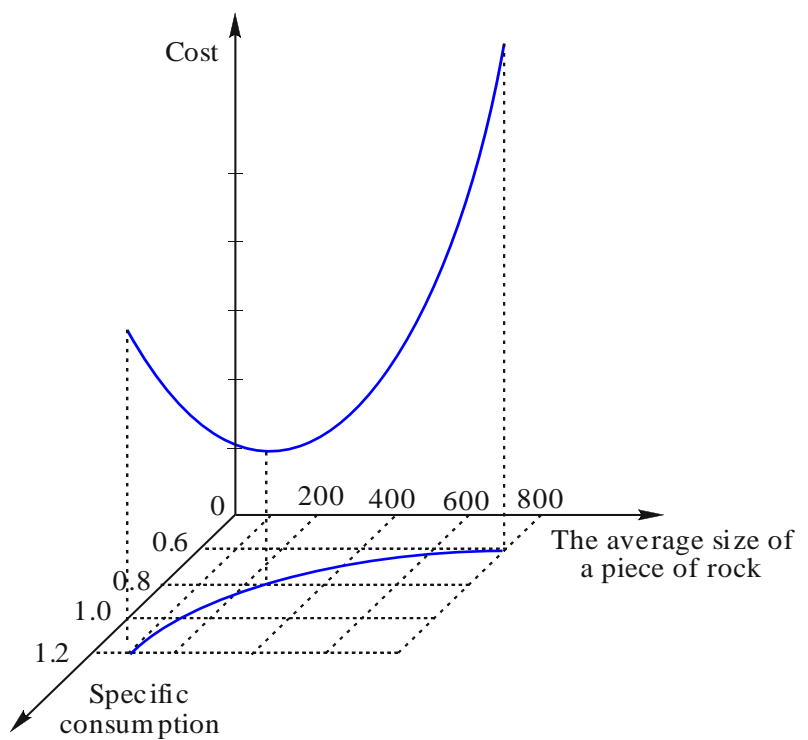

Figure 1. Graphic representation of the independence of the reduced cost for hard rock mining upon specific $E$ consumption and average rock size

It is almost impossible to develop a versatile physical model of stress field formation within hard rock mass making it possible to identify its fragmentation degree in terms of different types of drilling-and-blasting operations [9]. The abovementioned can explain the interest of scientists and researchers in the statistical analysis as applied to the real casual situations at each mining stage.

Increasing complexity of mining and geological as well as technical conditions of hard rock extraction, stipulated by the necessity to deepen open pit, needs more pragmatic and feasible approach as for the selection of methods to control set of drilling-and-blasting operations. Theoretical prerequisites to decide on rational firing parameters using computer modeling methods (i.e. problem-solving technique to analyze or synthesize complex multicriteria system) are known [10]. For the purpose, it was proposed to abstract from the nature of physical process of rock mass blasting to a model, evaluating its performance indicators. Standard deviations of such three performance indicators as fragmentation degree, shotpile width, and safe distance have been selected [11], [12].

However, the required granulometric rock mass composition is evaluated through a tolerance percent of oversize yield rather than average rock diameter being determined in terms of minimum direct costs for rock mass preparation under specific conditions. Moreover, there are no means to obtain operatively objective information on the hardness of rocks intended to be blasted massively [13].

Generally, use of the model to solve optimization problem is impossible due to high level of its complexity, and multidimensionality of possible alternate approaches.

Optimization of the basic DB parameters based upon their statistical analysis and consideration of direct costs in terms of each procedure is more productive at the stage of mining activity progress. Control of rock mass fracturing with the help of automation device provides sampling representativeness being the most important condition while compiling statistical distribution of its natural blockiness. Quantitative evaluation of rock mass fragmentation ability on the data, comparing volumes of oversize fractions contained in it before blasting and after it, differs in its originality and applicative relevance [14], [15].

Use of the method optimizing a set of DB operations in terms of minimum total costs per whole mining cycle will help improve performance indicators of the activities involving no extra means. Hence, determination of optimum resource distribution to execute DB under various blasting conditions is burning and crucial in the long term.

The objectives are as follows: to analyze regularities of changes in the reduced costs for drilling-and-blasting, loading and hauling, and fragmentation in the process of openpit mining of hard rock depending upon the value of machine-shift of the applied facility, its operation modes, hardness of rocks being blasted, cost of the used explosive, and rock mass fragmentation quality; to carry out sampling analysis of hard rock mass fracturing using automatic device; to use the findings to compile statistical distributions of its natural blockiness in terms of each bar taking into consideration its location as well as the whole well depth; to determine differential distribution function having the closest correlation with the observed feature; to identify the statistical dependence between a crushability factor of oversize blocks and specific consumption of the explosive being applied; to develop economic and mathematical model involving a target function of the total reduced expenditures connected with the operating processes, and set of constraints to avoid incorrect decisions; to represent a method to define optimum DB parameters in terms of minimum reduced costs per whole mining cycle using the economic and mathematical model solving; and to draw conclusions concerning implementation of DB optimization while controlling the operations at each stage of the hard rock deposit extraction.

\section{Methods}

Define expenditures connected with the performance of the basic technological mining operations depending upon structural behaviour of hard rock as well as the rock mass fragmentation. Costs for blasthole drilling reduced to $1 \mathrm{~m}^{3}$ of rock mass being mined are:

$$
E_{d r}=\frac{C_{d r} \cdot N_{d r}}{V_{b l} \cdot K_{l}},
$$

where:

$C_{d r}$ - machine-shift cost of the applied drill rig operation, UAH;

$N_{d r}$-number of the machine-shifts required to drill the block of rocks to be blasted;

$V_{b l}$ - block volume, $\mathrm{m}^{3}$;

$K_{l}-$ rock mass fragmentation index.

In this context:

$$
N_{d r}=\frac{l_{w} \cdot N_{w}}{P_{d r} \cdot T_{s h}},
$$

where: 
$l_{w}$ - well depth, m;

$P_{d r}-$ drill rig efficiency, $\mathrm{m} / \mathrm{h}$;

$T_{s h}-$ shift duration, h;

$N_{w}$ - number of wells from the rock block.

$N_{w}=\frac{V_{b l}}{(a \times b) \cdot h_{l}}$,

where:

$(a \times b)$ - the assumed parameters of well distribution, $\mathrm{m} \times \mathrm{m}$;

$h_{l}-$ bench height, $\mathrm{m}$.

According to [1]-[5], [11], [12], [16] and [17] studies, efficiency of roller-bit drilling rig, being common for open pits, is determined as follows:

$P_{d r}=\frac{k_{1}}{f^{2}} \sqrt{\frac{p n}{d}}$,

where:

$f$ - Protodyakonov hardness of the drilled rocks;

$p$-pressure developed within a hydraulic system of drill rig, atm;

$n$ - rotation frequency of a drilling assembly, rpm;

$d$-roller cone diameter, $\mathrm{mm}$;

$k_{1}$ - dimension coefficient.

Taking into consideration (1-4), the reduced expenditures connected with drilling operations are determined as follows:

$$
E_{d r}=\frac{C_{d r} \cdot f^{2} \cdot l_{w}}{K_{l} \cdot k_{1} \cdot(a \times b) \cdot h_{l} \cdot T_{s h}} \sqrt{\frac{d}{p n}} .
$$

The reduced costs for blasting operations are:

$$
E_{i m}=\frac{1}{V_{b l} \cdot K_{l}}\left(C_{h e} Q+C_{o v} V_{o v}\right)
$$

where:

$C_{h e}-$ cost per a ton of the applied E, UAH;

$Q$ - amount of E required to break down the rock block, t; $C_{o v}-$ cost for oversize fraction grinding, $\mathrm{UAH} / \mathrm{m}^{3}$;

$V_{o v}$ - oversize amount within the blasted rock mass, $\mathrm{m}^{3}$.

In this context:

$Q=0.001 g V_{b l} K_{l}$ and $V_{o v}=\left(\frac{d_{m d}}{d_{o v}}\right)^{3} V_{b l} K_{l}$,

where:

$g-$ specific E consumption, $\mathrm{kg} / \mathrm{m}^{3}$;

$d_{m d}$ - average rock within the blasted rock mass, m;

$d_{o v}$ - oversize dimension, $\mathrm{m}$.

$d_{o v}=0.8 \sqrt[3]{V_{s}}$

where:

$V_{s}-$ shovel size, $\mathrm{m}^{3}$.

Taking into consideration (6-8), the reduced expenditures, connected with blasting operations, are determined as follows:

$E_{i w}=0.001 C_{h e} g+C_{o v} \frac{2 d_{m d}^{3}}{V_{s}}$.

The reduced costs for the blasted rock mass loading using single bucket excavator are:

$$
E_{f}=\frac{C_{f} \cdot N_{f}}{V_{b l} \cdot K_{l}},
$$

where:

$C_{f}-$ cost of machine-shift of the applied excavator operation, UAH;

$N_{f}$-number of machine-shifts to load the blasted rock block.

$$
N_{f}=\frac{V_{b l} K_{l}}{P_{s} \cdot T_{s h}}
$$

where:

$P_{s}$ - applied excavator efficiency, $\mathrm{m}^{3} / \mathrm{h}$.

According to [3], [5], [18], [19] and [20], we have:

$$
P_{s}=\frac{2 P_{t} K_{f} K_{u}}{\left(1+e^{\left(\frac{d_{m d}}{d_{o v}}\right)^{2}}\right) K_{l}},
$$

where:

$P_{t}-$ theoretical efficiency of the excavator, $\mathrm{m}^{3} / \mathrm{h}$;

$K_{f}$ - bucket fill factor;

$K_{u}-$ coefficient involving a period of preparation and final operations.

Taking into consideration (10), (11) and (12), the reduced expenditures, connected with loading operations, are determined as follows:

$E_{f}=C_{f} \cdot \frac{\left(1+e^{\left(\frac{d_{m d}}{d_{o v}}\right)^{2}}\right) K_{l} K_{u}}{2 P_{t} \cdot K_{o v} \cdot T_{s h}}$.

The reduced costs for rock mass transportation by means of vehicles are:

$$
E_{T}=\frac{C_{T} \cdot N_{T}}{V_{b l} \cdot K_{l}},
$$

where:

$C_{T}$ and $N_{T}$ - costs of machine-shift of a dumper operation and their required number to transport rock mass of the blasted block respectively:

$$
N_{T}=\frac{v_{b l} \cdot K_{l} \cdot \gamma}{P_{T}}
$$

where:

$\gamma$ - volume weight of the rock mass, $\mathrm{t} / \mathrm{m}^{3} ;$

$P_{T}-$ dumper efficiency per shift, t/s.

$P_{T}=\frac{G \cdot T_{s h}}{t_{f l}}$,

where:

$G$-weight of rock mass transported per trip not exceeding the dumper capacity, $\mathrm{t}$;

$t_{f}$ - trip time, h. 
$t_{f l}=t_{l}+t_{d}$

where:

$t_{l}$ and $t_{d}$-loading time and travel time of the dumper respectively, h.

$t_{l}=\frac{G}{P_{s} \cdot \gamma}$.

Hence,

$t_{f l}=\frac{G}{P_{s} \cdot \gamma}+t_{d}$

Taking into consideration (12), (15), (16), (18) and (19), the reduced expenditures, connected with rock mass transportation by means of vehicles, are determined as follows:

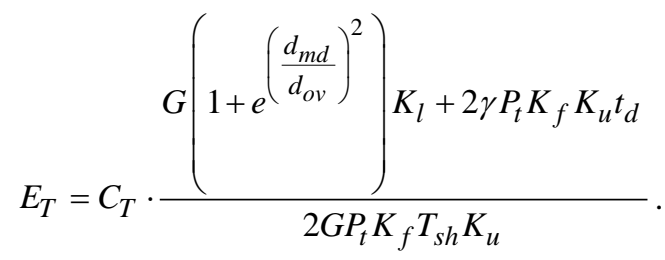

The reduced costs for the mineral crushing are:

$$
E_{c r}=\frac{C_{c r} \cdot N_{c r}}{V_{b l} \cdot K_{l}},
$$

where:

$C_{c r}$ and $N_{c r}-$ cost of a machine-shift of the applied mill operation and the number of machine-shifts required to crush rock mass of the blasted block.

$N_{c r}=\frac{V_{b l} \cdot K_{l} \cdot \gamma}{P_{c r} \cdot T_{s h}}$

where:

$P_{c r}-$ technical performance of the applied mill, $\mathrm{t} / \mathrm{s}$;

$P_{c r}=P_{u} \cdot K_{c r}$

where:

$P_{u}$ - design capacity of the applied mill;

$K_{c r}$ - coefficient of the mill use depending upon granulometric composition of the blasted rock mass.

Statistical analysis of the basic indices of rock mass crushing has been performed. It concerned different sizes of rocks as well as their hardness. In this, fragmentation quality of the rock mass during blasting was evaluated objectively using a purposely designed automation [12], [21] and [22]. Moreover, similar studies were carried out under laboratory conditions using simulation of stage one of hard rock crushing. To this effect, experimental model of jaw breaker was manufactured to decompose freeform rocks with maximum 60-80 $\mathrm{mm}$ dimensions in terms of 4-5 compression degree, and $f=10-18$ allowable rock hardness (Fig. 2).

Following dependence results from the studies:

$$
K_{c r}=e^{-4 \cdot 10^{-6} d_{m d} \sqrt{d_{m d} f}}
$$

Taking into consideration (21), (22), (23) and (24) the reduced expenditures, connected with the rock mass fragmented by blasting into various degrees of largeness, are determined as follows:

$$
E_{c r}=C_{c r} \cdot \frac{\gamma e^{4 \cdot 10^{-6} d_{m d} \sqrt{d_{m d} f}}}{P_{p} \cdot T_{s h}}
$$

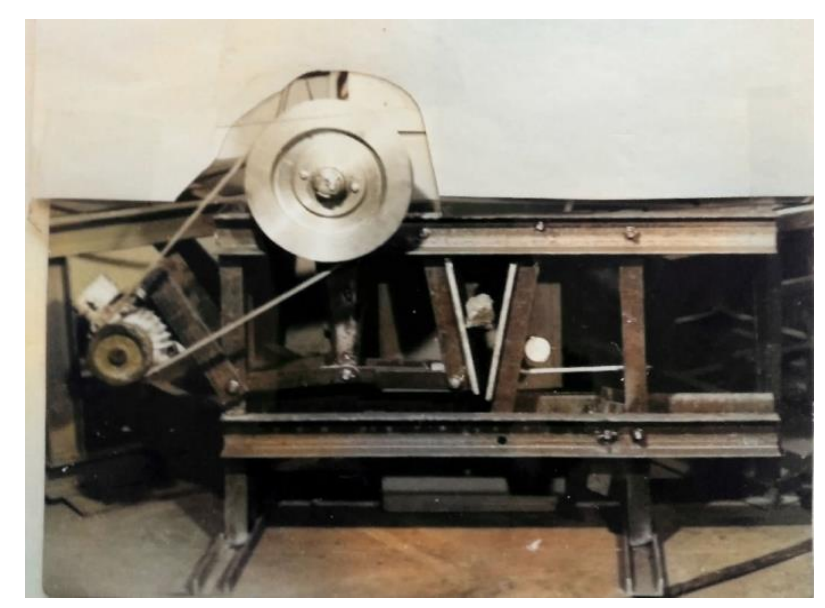

Figure 2. General configuration of the experimental jaw breaker

To evaluate the effect of DB means on the fragmentation degree of rock mass, statistical studies of a process of its granulometric formation have been carried out taking into consideration structural behaviour of the hard rock mass as well as the applied force field [23] and [24].

It is proposed to consider hard rock fragmentation by means of blasting in the form of a transitional process from one degree of its fracturing being both of natural and engineering nature (i.e. natural blockiness) to another one being more intensive owing to the blasted E. Distribution of the natural blockiness within the rock mass was evaluated basing upon the objective information obtained with the help of the manufactured device which used a radial chart to record drops of pressure within a hydraulic system of a roller-bit drilling rig observed when its operating bit was passing cavities. Figure 3 is typical representation of the record.

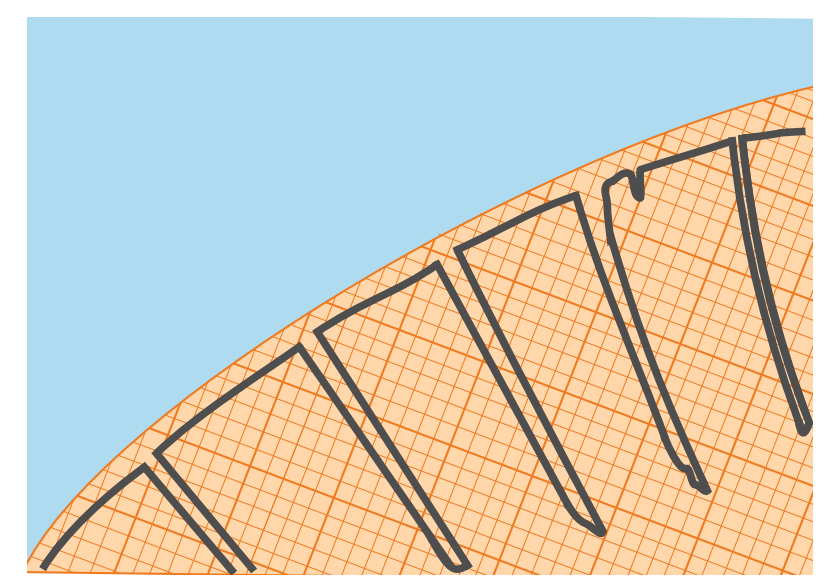

Figure 3. Fragment of the radial chart with the drilled rock fracturing

Distance between the pressure drops within a hydraulic system of a drilling rig, recorded by the diagram, characterizes a size of the natural rock block in terms of its height; the drop depth characterizes opening degree of cavities between the blocks. Hence, it becomes possible to evaluate objectively preliminary fragmentation of the blasted rock mass. 


\section{Results and discussion}

Thirty granite open pits, producing gravel, were involved in the statistical observations. A random selection method was applied for each of them to identify four wells drilled by means of a rig equipped with the mentioned device. The diagrams were interpreted differentially in terms of each bar length $(8 \mathrm{~m})$, taking into consideration its location relative to a bench height, as well as depth of the drilled well $(16 \mathrm{~m})$. The observations results were summarized in groups involving ten wells each; that is why the total number of natural separateness (i.e. blocks) within a group was a sample for it. Table 1 shows statistical distributions of the dimensions of natural blocks in terms of three measurement types (bar and well) for the most representative group of the wells.

Table 1. Statistical representation of natural blockiness of the rock according to three samples

\begin{tabular}{|c|c|c|c|c|c|c|c|c|c|c|c|}
\hline \multicolumn{2}{|c|}{$x_{i}, x_{i+1}$} & $0 ; 0.4$ & $0.4 ; 0.8$ & $0.8 ; 1.2$ & $1.2 ; 1.6$ & $1.6 ; 2.0$ & $2.0 ; 2.4$ & $2.4 ; 2.8$ & $2.8 ; 3.2$ & $3.2 ; 3.6$ & $\sum_{i=1}^{9}$ \\
\hline \multicolumn{2}{|c|}{$\overline{x_{i}}$} & 0.2 & 0.6 & 1.0 & 1.4 & 1.8 & 2.2 & 2.6 & 3.0 & 3.4 & \\
\hline \multirow{2}{*}{$l_{u}$} & $n_{i}$ & 50 & 42 & 26 & 24 & 16 & 11 & 6 & 3 & 2 & 180 \\
\hline & $m_{i}$ & 0.28 & 0.24 & 0.14 & 0.13 & 0.09 & 0.06 & 0.03 & 0.02 & 0.01 & 1.0 \\
\hline \multirow{2}{*}{$l_{b}$} & $n_{i}$ & 1 & 26 & 28 & 19 & 14 & 12 & 10 & 6 & 4 & 120 \\
\hline & $m_{i}$ & 0.01 & 0.22 & 0.23 & 0.16 & 0.12 & 0.1 & 0.08 & 0.05 & 0.03 & 1.0 \\
\hline \multirow{2}{*}{$l$} & $n_{i}$ & 51 & 68 & 54 & 43 & 30 & 23 & 16 & 9 & 6 & 300 \\
\hline & $m_{i}$ & 0.17 & 0.23 & 0.18 & 0.14 & 0.1 & 0.08 & 0.05 & 0.03 & 0.02 & 1.0 \\
\hline
\end{tabular}

Symbols:

$x_{i}, x_{i+1}$ - are intervals of sizes of natural separateness obtained while the diagram interpreting; $h=0.4 \mathrm{~m}$ is interval length;

$\bar{x}_{i}-$ centres of the intervals;

$l_{u}, l_{b}, l$ - measurements on the upper bar, lower bar, and well length respectively;

$n_{i}, m_{i}-$ variants and frequencies.

Table 2 explains basic characteristics of the distributions.

Table 2. Evaluations of the statistical distributions

\begin{tabular}{cccc}
\hline $\begin{array}{c}\text { Measurement } \\
\text { type }\end{array}$ & $\begin{array}{c}\text { Sample } \\
\text { volume, } n\end{array}$ & $\begin{array}{c}\text { Mathematical } \\
\text { expectation, } M(x)\end{array}$ & $\begin{array}{c}\text { Standard } \\
\text { deviation, } \sigma(x)\end{array}$ \\
\hline$l_{u}$ & 180 & 1.0 & 0.76 \\
\hline$l_{b}$ & 120 & 1.5 & 0.84 \\
\hline$l$ & 300 & 1.2 & 0.91 \\
\hline
\end{tabular}

As it follows from Table 2, sample volume in terms of $l_{u}$ measurement is more than in terms of $l_{b}$. The abovementioned can be explained by extra fragmentation of the upper bench share using blasting of charges located in overdrills of wells within a level above the bench [25] and [26]. Along the well length $(l)$, blockiness is involved in terms of both measurements. Hence, mathematical expectation is an intermediate and standard deviation exceeds previous ones. Figure 4 demonstrates frequency diagrams of the considered statistical distributions.

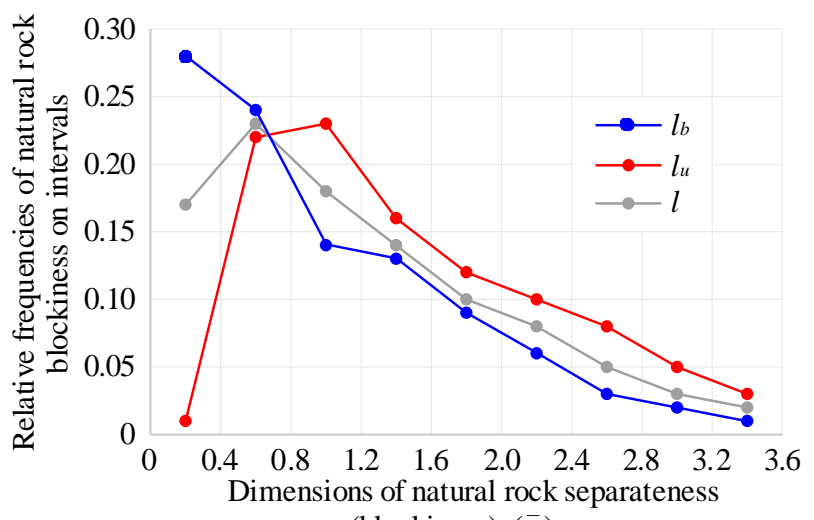

(blockiness), $\left(\bar{x}_{i}\right), \mathrm{m}$

Figure 4. Frequency polygons of statistical distributions of hard rock blockiness

Apply visual selection of a model to distribute random value of $x$, i.e. dimensions of natural blocks into which fracturing divides the hard rock mass [27]. A form of the frequency polygon to measure $l_{u}$ resembles exponential curve; in turn, frequency polygons for $l_{b}$ and $l$ differ fundamentally from it.

Hence, it is impossible to simulate all distributions of a random $\mathrm{x}$ value with the help of one-parameter function. Apply two-parameter G-distribution in terms of which exponential distribution of the same random value is the special case [28]. Differential function of G-distribution (i.e. density) is as follows:

$f(x)=\left\{\begin{array}{l}0 \quad \text { at } \quad x<0 \\ \frac{\beta^{\alpha}}{\Gamma(\alpha)} x^{\alpha-1} e^{-\beta x} \quad \text { at } \quad x \geq 0\end{array}\right.$,

where:

$\alpha$ and $\beta$-positive parameters;

$\Gamma(\alpha)$ - Euler Gamma function $\Gamma(\alpha)=\int_{0}^{\infty} x^{\alpha-1} e^{-x} d x$.

It should be mentioned that $\Gamma(\alpha)=\frac{\alpha-1}{\Gamma(\alpha-1)}$; moreover, if $\alpha$ is a positive integer then $\Gamma(\alpha)=\alpha$ !. In this context, $\Gamma(1)=1$.

If $\alpha=1$ and $\beta=1 / \lambda$ then we will obtain exponential distribution of a random $x$ value with the density:

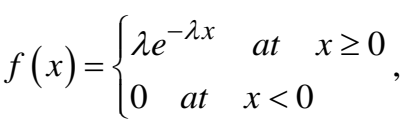

where:

$\lambda$ - positive parameter.

Analyze correspondence of the assumed distribution law of random $x$ feature with data of statistical processing of sample observations in terms of each measurement (Tables 1 and 2). To perform measurements within the upper bench share $\left(l_{b}\right)$, apply (27) formula, if $M(x)=1$ and $\lambda=1$ 
$(M(x)=1 / \lambda$ is for exponential distribution). When $x \geq 0$, we have:

$f(x)=e^{-x}$.

Table 3 demonstrates the function values for the observed $x_{\mathrm{i}}$ of the random $x$ value.

Table 3. Values of differential function of natural rock blockiness while measuring $l_{u}$

\begin{tabular}{cccccccccc}
\hline $\bar{x}_{i}$ & 0.2 & 0.6 & 1.0 & 1.4 & 1.8 & 2.2 & 2.6 & 3.0 & 3.4 \\
\hline$f\left(\bar{x}_{i}\right)$ & 0.82 & 0.55 & 0.37 & 0.25 & 0.17 & 0.11 & 0.08 & 0.05 & 0.03 \\
\hline
\end{tabular}

Compare the function graph with frequency polygon of statistical distribution of natural blockiness (Fig. 5).

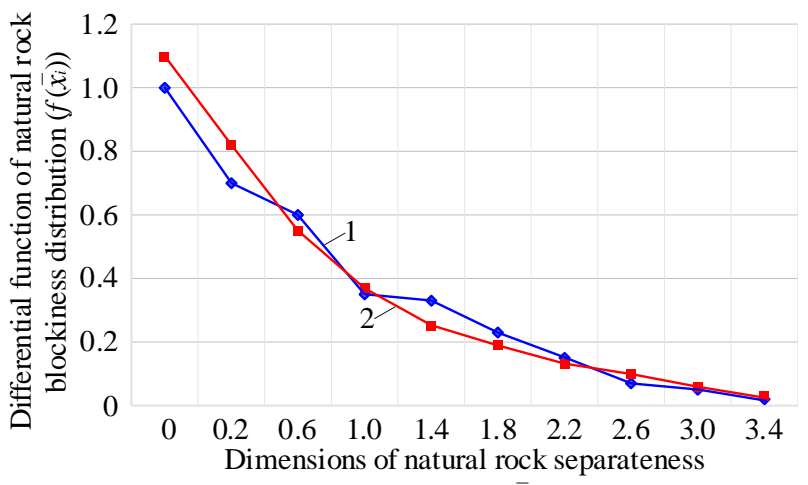

(blockiness), $\left(\bar{x}_{i}\right), \mathrm{m}$

Figure 5. Distribution of natural hard rock blockiness for $l_{u}$ : 1 density value $f(x) ; 2$ - polygon of relative frequencies $W i$

To perform measurements within the lower bench share $\left(l_{b}\right)$, apply (26) formula and following ratios:

$$
M(x)=\alpha \beta, D(x)=\alpha \beta^{2} \text {. }
$$

While solving simultaneously the equations for $M(x)=1.5$ and $\sigma=0.84$ (Table 2), we find that $\alpha=3.2$. Assume integer value $\alpha=3$; then, $\beta=0.5$. Taking into consideration the parameter values, distribution density is as follows:

$$
f(x)=4 x^{2} e^{-2 x} \text {. }
$$

Table 4 shows values of the function.

Figure 6 demonstrates the represented function graph together with the polygon of relative frequencies.

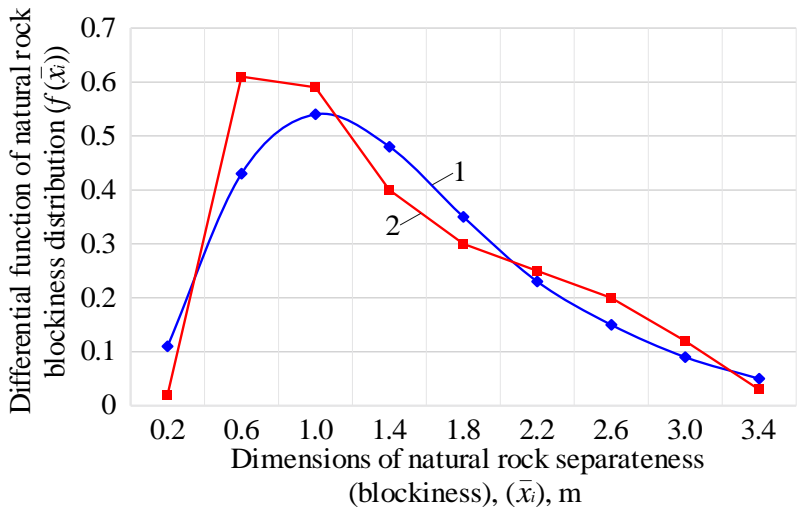

Figure 6. Graphs of natural rock blockiness distribution for $l_{b}: 1-$ density value $f(x) ; 2$-polygon of relative frequencies $W_{i}$

Measurements throughout the well length $(l)$ are performed as follows. While solving simultaneously (28) equation for $M(x)=1.2$ and $\sigma=0.91$ (Table 2), we find that $\alpha=1.74$. Apply $\alpha=2$; then $\beta=0.6$.

In this context, distribution density is:

$f(x)=2.78 x e^{-1.67 x}$.

Table 5 contains values of the function. Figure 7 demonstrates the function graph together with the relative frequency.

Table 4. Values of distribution density of natural blockiness if $l_{b}$ is measured

\begin{tabular}{lccccccccc}
\hline$\overline{x_{i}}$ & 0.2 & 0.6 & 1.0 & 1.4 & 1.8 & 2.2 & 2.6 & 3.0 & 3.4 \\
\hline$f\left(\bar{x}_{i}\right)$ & 0.11 & 0.43 & 0.54 & 0.48 & 0.35 & 0.23 & 0.15 & 0.09 & 0.05 \\
\hline
\end{tabular}

Table 5. Values of distribution density of natural blockiness if $l$ is measured

\begin{tabular}{lccccccccc}
\hline $\bar{x}_{i}$ & 0.2 & 0.6 & 1.0 & 1.4 & 1.8 & 2.2 & 2.6 & 3.0 & 3.4 \\
\hline$f\left(\bar{x}_{i}\right)$ & 0.4 & 0.61 & 0.53 & 0.37 & 0.25 & 0.15 & 0.09 & 0.06 & 0.03 \\
\hline
\end{tabular}

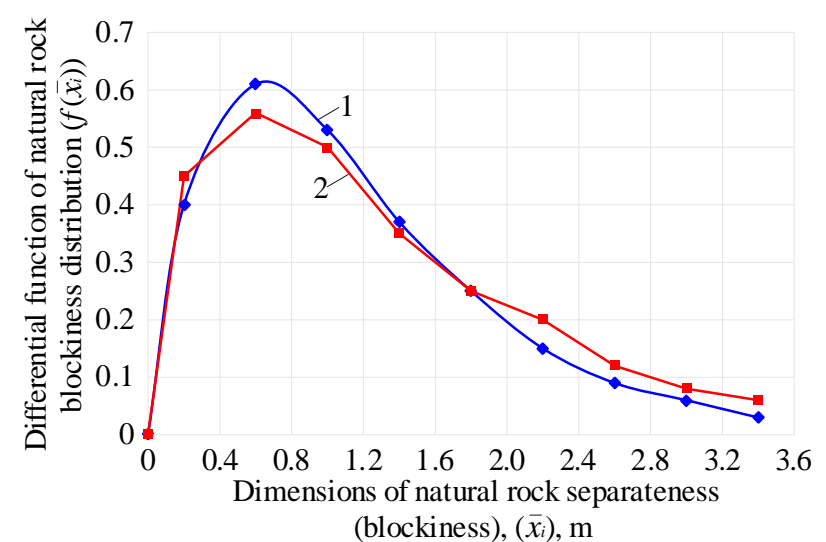

Figure 7. Graph of rock natural blockiness distribution to observe l: 1 -density value $f(x) ; 2$ - relative frequency polygon $\mathrm{Wi}$
Visual comparison of Figures 3, 4, and 5 makes it possible to conclude that statistical distribution of natural blockiness within the hard rock mass can be simulated in the closest manner by means of the differential function throughout the well length $(l)$. Relying upon the fact and serving the engineering acceptability of statistical evaluation of rock blastability, consider use of mathematical modeling only from the viewpoint of the mined block height $(l)$ [29]. In this context, distribution density is as follows:

$f(x)=\frac{1}{\beta^{2}} x e^{-\frac{x}{\beta}}$.

Forecast the content of oversize natural blocks within the rock, i.e.: 
$\Delta_{H}=1-\frac{1}{\beta^{2}} \int_{0}^{d_{H}} x e^{-\frac{x}{\beta}} d x$

where:

$\Delta_{H}$ - content of natural oversize blocks;

$d_{H}$ - dimensions of a block considered as the oversize one depending upon the applied mining and hoisting facilities.

While integrating by parts (7), we determine:

$\Delta_{H}=1+\frac{1}{\beta^{2}}\left(e^{-\frac{x}{\beta}}\left(d_{H}+\beta\right)-\beta\right)$.

It is customary to mining that $d_{H}=0.8 \sqrt[3]{V_{s h}}$, where $V_{s h}$ is bucket capacity of loading shovel; in term of a crawler mounted mining shovel $-4,6$, it is $d_{H}=1.3 \mathrm{~m}$; then, $\Delta_{H}=0.37$ or $37 \%$.
Oversize content within the blasted rock mass $\Delta_{H}^{\prime}$ was evaluated on those rock blocks where natural blockiness was observed statistically. As a result, $K_{H}$ (i.e. oversize crushability factor) was determined in terms of each measurement:

$K_{H}=\frac{\Delta_{H}^{\prime}}{\Delta_{H}}$.

The factor dependence upon the blasted rock strength $(f)$ as well as upon specific E consumption $(g)$ has been identified with the help of the statistical function:

$$
K_{H}=0.002 \frac{f}{g^{2}} .
$$

Table 6 shows values of $K_{H}$ factor calculated using the formula. Figure 8 demonstrates schematic graph of the function.

Table 6. The calculated values of $K_{H}$ factor

\begin{tabular}{ccccccccccccccccc}
\hline$f$ & \multicolumn{4}{c}{14} & \multicolumn{1}{c}{16} & \multicolumn{1}{c}{18} & \multicolumn{1}{c}{20} \\
\hline$g$ & 0.4 & 0.6 & 0.8 & 1.0 & 0.4 & 0.6 & 0.8 & 1.0 & 0.4 & 0.6 & 0.8 & 1.0 & 0.4 & 0.6 & 0.8 & 1.0 \\
\hline$K_{H}$ & 0.17 & 0.08 & 0.04 & 0.03 & 0.2 & 0.09 & 0.05 & 0.03 & 0.23 & 0.1 & 0.06 & 0.04 & 0.25 & 0.11 & 0.08 & 0.04 \\
\hline
\end{tabular}

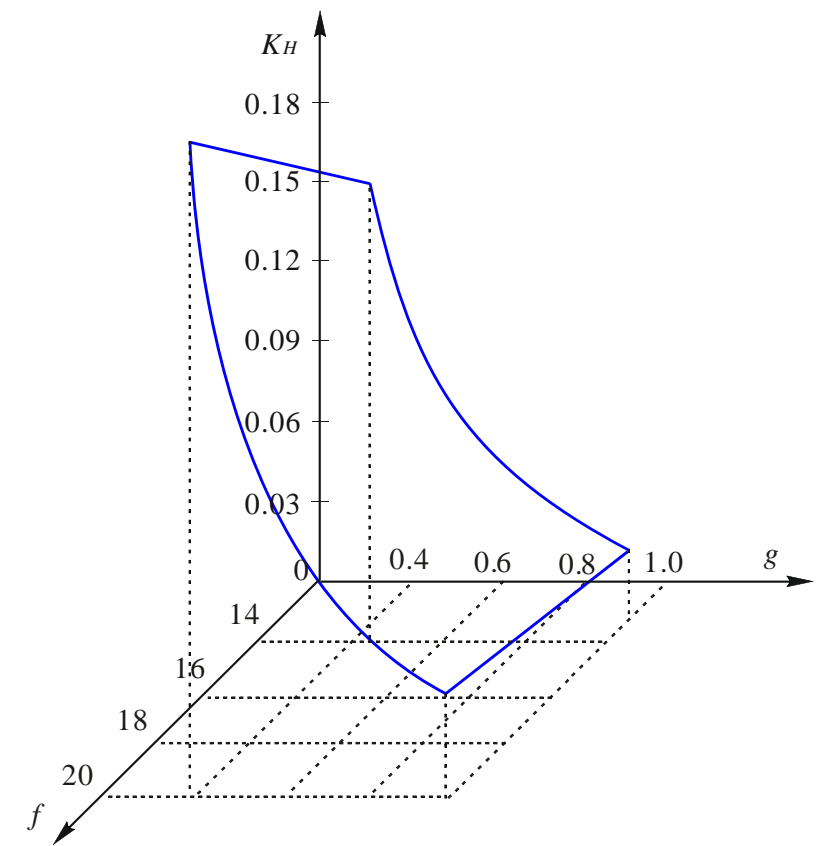

Figure 8. Dependence graph of the oversize crushing factor of natural blockiness $\left(K_{H}\right)$ upon the rock strength and specific E consumption ( $g$ )

Consider transition of natural blockiness of rock mass to rock mass under explosion energy. Use the case when $f=18$ and $g=0.8$ being typical for granite fragmentation. In this context, $K_{H}=0.053$ (according to 36 ) and $\Delta_{H}=0.37$; then, $\Delta_{H}^{\prime}=0.02$. Apply $\Delta_{H}^{\prime}$ instead of $\Delta_{H}$ to (34):

$0.02=1+\frac{1}{\beta}\left(e^{-\frac{d_{H}}{\beta}}\left(d_{H}+\beta\right)-\beta\right)$

Relative to $\beta$ (if $d_{H}=1.3$ ), the equation solution helps determine that its value is 0.22 ; i.e. $\beta=0.22$. While substituting it into (32), we obtain distribution density of rock mass granulometric composition instead of distribution of natural rock blockiness under the same mining and geological conditions: $f(x)=\frac{1}{(0.22)^{2}} x e^{-\frac{x}{0.22}}$

Table 7 shows values calculated on the formula.

Table 7. Values of differential function of rock mass granulometric composition distribution

\begin{tabular}{ccccccc}
\hline$x$ & 0.2 & 0.6 & 1.0 & 1.4 & 1.8 & 2.2 \\
\hline$f(x)$ & 1.67 & 0.81 & 0.21 & 0.05 & 0.01 & 0.002 \\
\hline
\end{tabular}

Figure 9 demonstrates a graph representing transition of natural rock blockiness (Table 7) to rock mass resulting from the rock blasting.



Figure 9. Mapping of a function of granulometric composition of rock mass resulting from blasting operations, onto natural blockiness distribution function under the same conditions: 1-distribution graph of granulometric composition of rock mass; 2 -distribution graph of natural blockiness of rock blastability

The graphs, represented in Figure 9, illustrate qualitative changes in rock mass crushing under fissuring into smaller fragments under the effect of explosion energy ([5], [12], [27]). For the first time, statistical simulation of the considered technological process makes it possible to involve qualitatively a degree of preliminary rock destruction while selecting DB parameters ([11], [22], [29]). 
Average rock size, forecasted for the parameters, is determined by means of mathematical expectation of the assumed G-distribution, i.e. $d_{m d}=\alpha \beta$. It has been defined during natural density of granite mass measuring on a well depth $(l)$ that the most probable values of $\alpha$ parameter are within (1.65-2.3) interval. Using the a ccuracy, being tolerable for mining, assume its integer value $(\alpha=2)$ to simplify significantly subsequent calculations. $\beta$ parameter is determined based on condition (34) for $\Delta_{H}^{\prime}$ estimated using (35) and (36) formulae.

Integrally, economic and mathematical optimization model of DB complex is:

$$
E=\sum_{i} \sum_{j} E_{i j}+\sum_{i} E_{i}
$$

where:

$$
E \rightarrow \min \text { if } \frac{4 \cdot 10^{6} g(a \cdot b) h_{l} K_{l}}{\pi d_{w}^{2} \gamma_{h e}}<l_{3}, l_{c}=l_{w}-l_{i s},
$$

where:

$E_{i j}$ - reduced expenditures connected with DB operations (formulae (5) and (9));

$E_{i}$ - reduced expenditures connected with loading and hauling operations as well as the mineral crushing (13), (20), and (25) formulae);

$d_{w}$ - a well diameter, $\mathrm{mm}$;

$\gamma_{h e}$ - volume weight of the applied $\mathrm{E}, \mathrm{kg} / \mathrm{m}^{3}$;

$L_{c}$ and $l_{i s}$ - borehole charge length and inertial stemming length, $\mathrm{m}$, respectively.

Figure 10 explains a structural scheme of the model implementation.

The represented model to select optimal DB parameters will be implemented in the algorithm controlling a complex of the operations in terms of a criterion of minimum total expenditures connected with the basic technological processes of open-pit hard rock mining.

\section{Conclusions}

The statistical analysis of operating costs in the process of roller-bit drilling rig and loading shovel operation has been performed relying upon the objective information obtained using the developed automation devices.

A function of the total costs for DB operations depending upon the applied parameters under the specific mining and geological conditions has been defined.

A function of the total costs for loading-unloadinghoisting operation as well as rock mass crushing depending upon its forecasted fragmentation quality while implementing different DB parameters has been determined.

Statistical studies of natural blockiness of rock, being blasted in granite open pits producing gravel, have been carried out. In this context, sample representativeness was provided owing to the use of the applied device helping record fissuring on the pressure drop within a hydraulic system of roller-bit drilling rig.

Statistical distributions of natural rock blockiness have been compiled on the height of each bar, taking into consideration its location, as well as throughout the well length. It has been proposed to approximate them with the help of twoparameter G-distribution.

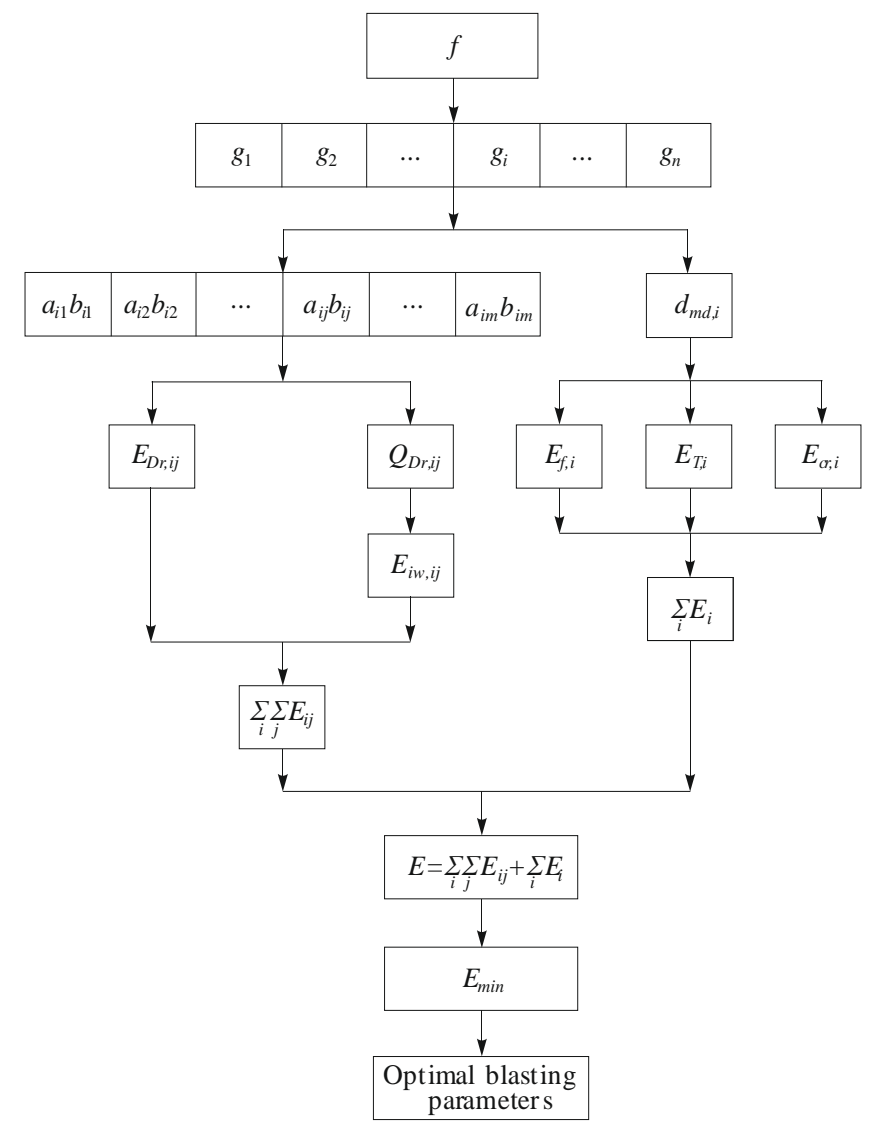

Figure 10. Logical diagram to optimize DB operations in open pits

It has been identified visually that the assumed G-distribution has the closest correlation with the statistical blockiness distribution while measuring throughout the well depth; the abovementioned is also processible during observations. The measurement type has been approved for further studies.

A method has been proposed to transform distribution function of natural rock blockiness into the forecasted function of distribution of granulometric composition of rock mass obtained while the formation fragmenting using DB operations according to the approved schedule. On the basis of the method, statistical dependence between average rock size and blasting conditions has been defined.

Economic and mathematical model of the total reduced expenditures, connected with whole mining cycle, has been compiled inclusive of a target function and set of constraints.

Logical diagram to select optimum DB parameters in terms of minimum total costs has been proposed.

In the long run, the logical diagram will be used as the basis of an algorithm for optimum control of DB complex in terms of various rock strength parameters.

\section{Acknowledgements}

This work was supported by the Ministry of Education and Science of the Republic of Kazakhstan, grant No. AP08857087. The authors express their thanks to Viktor Ivanovych Bondarets, Engineering Director of Pokrovskyi HirnychoZbahachuvalnyi Kombinat JSC, for his expert advice on technological processes in open pits. The authors are grateful to Anatilii Yuriiovych Dryzhenko, Doctor of Engineering, Professor, Academician of the Dnipro University of Technology for his substantial and pertinent remarks concerning research and development in the process of the paper writing. 


\section{References}

[1] Frolov, O.O., \& Kosenko, T.V. (2020). Vidkryti hirnychi roboty. Chastyna I. Protsesy vidkrytykh hirnychykh robit. Kyiv, Ukraina: KPI im. Ihoria Sikorskoho, $151 \mathrm{~s}$.

[2] Vinogradov, Yu.I., \& Hohlov, S.V. (2015). Metod raschota parametrov burovzryvnykh rabot na zadannyy granulometricheskiy sostav vzorvannoy gornoy massy. Gornyy Informatsionno-Analiticheskiy Byulleten', (S1), 20-29.

[3] Shcherbakov, P., Klymenko, D., \& Tymchenko, S. (2017). Statistical research of shovel excavator performance during loading of rock mass of different crushing quality. Scientific Bulletin of National Mining University, (1), 49-54.

[4] Vilkul, Yu.G., \& Peregudov, V.V. (2011). The influence of grain size composition of blasted rock mass on open pit performance indicators. Ore Mining, 2(96), 3-7.

[5] Shcherbakov, P.M., \& Balashov, S.V. (2010). Statystychnyi pidkhid do obgruntuvannia parametriv buro-vybukhovykh robit na karierakh. Zbirnyk Naukovykh Prats Natsionalnoho Hirnychoho Universytetu, (35), 12-21.

[6] Potresov, D.K., Belin, V.A., \& Sapozhnikov, S.I. (2007) Determinirovannye metody i algoritmy mnogokriterial'nogo prognoza kachestva vzryvnyh rabot na kar'ere. Gornyy Informatsionno-Analiticheskiy Byulleten', 139-146.

[7] Sazid, M., \& Singh, T.N. (2015). Numerical assessment of spacingburden ratio to effective utilization of explosive energy. International Journal of Mining Science and Technology, 25(2), 291-297. https://doi.org/10.1016/j.ijmst.2015.02.019

[8] Minchinton, A. (2015). On the influence of fundamental detonics on blasting practice. Proceedings of the $11^{\text {th }}$ International Symposium on Rock Fragmentation by Blasting, 41-53.

[9] Hasanipanah, M., Jahed Armaghani, D., Monjezi, M., \& Shams, S. (2016). Risk assessment and prediction of rock fragmentation produced by blasting operation: A rock engineering system. Environmental Earth Sciences, 75(9), 808. https://doi.org/10.1007/s12665-016-5503-y

[10] Motazavi, A., \& Katsabanis, P.D. (1999) Application of discontinuous deformation analysis to the modelling of rock blasting in mining. Proceedings of the $37^{\text {th }}$ US Rock Mechanics Symposium, 543-550.

[11] Rakishev, B.R., Auezova, A.M., \& Rakisheva, Z.B. (2014). The specification of granulometric composition of natural jointing in the rock massif by their average size. Proceedings of the $9^{\text {th }}$ International Conference on Physical Problems of Rock Destruction, 274-282.

[12] Shcherbakov, P., Tymchenko, S., Buhrym, O., \& Klymenko, D. (2019). Research into the crushing and grinding processes of iron ore with its simultaneous effect by mechanical load and electric field of ultra-high frequency. E3S Web of Conferences, (123), 01030. https://doi.org/10.1051/e3sconf/201912301030

[13] Shashenko, O.M., Sdvyzhkova, O.O., \& Kovrov, O.S. (2010). Modelling of the rock slope stability at the controlled failure. Rock Mechanics in Civil and Environmental Engineering, 581-584.

[14] Sdvyzhkova, O., Golovko, Yu., \& Klymenko, D. (2017). Effect of harmonic oscillations on a crack initiation in the rock mass. Naukovyi Visnyk Natsionalnoho Hirnychoho Universytetu, (4), 13-18.

[15] Prykhodchenko, V.F., Sdvyzhkova, O.O., Khomenko, N.V., \& Tykhonenko, V.V. (2016). Effect of time-transgressive faults upon methane distribution within coal seams. Naukovyi Visnyk Natsionalnoho Hirnychoho Universytetu, (1), 31-35.

[16] Drobakhin, O.O., \& Olevskyi, O.V. (2018). Verification of applicability in space domain of the inverse filtering with evolution control for reconstruction of images obtained by radar scanning. AIP Conference Proceedings, 050002. https://doi.org/10.1063/1.5064904

[17] Olevska, Y.B., Olevskyi, V.I., \& Olevskyi, O.V. (2018). Using of fuzzy mathematical models in automated systems for recognition of high molecular substances. AIP Conference Proceedings, 060003. https://doi.org/10.1063/1.5064911

[18] Mossakovskii, V.I., Mil’tsyn, A.M., Selivanov, Y.M., \& Olevskii, V.I (1994). Automating the analysis of results of a holographic experiment. Strength of Materials, 26(5), 385-391. https://doi.org/10.1007/bf02207425

[19] Kolosov, D., Dolgov, O., Bilous, O., \& Kolosov, A. (2015). The stressstrain state of the belt in the operating changes of the burdening conveyor parameters. New Developments in Mining Engineering 2015: Theoretical and Practical Solutions of Mineral Resources Mining, 585-590. https://doi.org/10.1201/b19901-101

[20] Ilin, S.R., Samusya, V.I., Ilina, I.S., \& Ilina, S.S. (2017). Influence of dynamic processes in mine hoists on safety of exploitation of shafts with Broken geometry. Naukovyi Visnyk Natsionalnoho Hirnychoho Universytetu, (3), 48-53.

[21] Babets, D., Sdvyzhkova, O., Shashenko, O., Kravchenko, K., \& Cabana, E.C. (2019). Implementation of probabilistic approach to rock mass strength estimation while excavating through fault zones. Mining of Mineral Deposits, 13(4), 72-83. https://doi.org/10.33271/mining13.04.072

[22] Babets, D. (2018) Rock mass strength estimation using structural factor based on statistical strength theory. Solid State Phenomena, (277), 111122. https://doi.org/10.4028/www.scientific.net/SSP.277.111

[23] Tereshchuk, R.M., Khoziaikina, N.V., \& Babets, D.V. (2018). Substantiation of rational roof-bolting parameters. Naukovyi Visnyk Natsionalnoho Hirnychoho Universytetu, (1), 19-26.

[24] Motazavi, A., \& Katsabanis, P.D. (1999). Application of discontinuous deformation analysis to the modelling of rock blasting in mining. Proceedings of the $37^{\text {th }}$ US Rock Mechanics Symposium, 543-550.

[25] Khomenko, E.M., Ponomarenko, I.A., Ishchenko, K.S., \& Kratkovsky, I.L. (2019). Modernization and engineering development of resourcesaving technologies in mineral mining and processing. Multi-authored monograph, 264-280.

[26] Bitimbaev, M.Zh. (2019). Novye varianty sistemy razrabotki s magazinirovaniem: kardinal'noe uluchshenie pokazateley dobychi. Gornyy Zhurnal Kazahstana, (7), 8-14.

[27] Rakishev, B., Tambiev, P.G., Bitimbaev, M.Zh., \& Frank, A.E. (2016). Tekhnologiya i osobennosti sensibilizacii patronirovannyh EVV NPP “INTERRIN". Vzryvnoe Delo, 115(72), 96-114.

[28] Sdvyzhkova, O., Golovko, Y., \& Klimenko, D. (2017). Theoretical substantiation of the rock outburst criterion in terms of amplitudefrequency characteristics of an acoustic signal. $16^{\text {th }}$ International Conference on Geoinformatics - Theoretical and Applied Aspects. https://doi.org/10.3997/2214-4609.201701822

[29] Shashenko, A.N., Zhuravlev, V.N., Sdvizhkova, E.A., \& Dubickaya, M.S. (2015). Prognoz diz'unktivov na osnove matematicheskoy interpretacii fazovykh kharakteristik akusticheskikh signalov. Scientific Bulletin of National Mining University, (2), 61-66.

\section{Математична модель оптимізації буропідривних робіт при відкритій розробці родовищ скельних корисних копалин}

\section{П. Щербаков, С. Тимченко, М. Бітімбаєв, Н. Сарибаєв, С. Молдабаєв}

Мета. Визначення функції приведених витрат на буропідривні, вантажно-транспортні роботи і механічне дроблення залежно від вартості машино-зміни застосовуваного технічного засобу, режимів його експлуатації, міцності підриваємих порід, вартості застосовуваної вибухової речовини та якості дроблення гірничої маси на основі розробленої математичної моделі оптимізації.

Методика. Застосовано метод статистичної оцінки природної блочності скельної породи та якості її дроблення енергією вибуху. Виконано статистичні дослідження основних показників процесу механічного дроблення гірничої маси різної крупності й міцності складових іiї шматків. За допомогою спеціально розробленого зразка експериментального обладнання проведені вибіркові дослідження тріщинуватості породи в процесі ії буріння шарошечним верстатом, що забезпечило репрезентативність вибірки.

Результати. Складено статистичні розподіли блочності породи за довжиною кожної штанги з урахуванням її положення в буровому ставі, а також за глибиною свердловини. Встановлено візуальним порівнянням експериментальних і теоретичних даних, що статистичні розподілу природної блочності породи тісно корелюють з гамма-розподілом, диференціальна функція якого має два додатних параметра. Встановлена статистична залежність між результатами буропідривних робіт і сумарними витратами на видобуток скельних корисних копалин.

Наукова новизна. Запропоновано поняття коефіцієнта дроблення негабариту та отримана його статистична залежність від міцності розробляємої породи і питомої витрати застосованої вибухової речовини. Запропоновано варіант зміни параметрів диференціальної функції прийнятого гамма-розподілу стосовно прогнозованого гранулометричному складу гірничої маси. 
Практична значимість. Складено економіко-математичну модель, що включає цільову функцію сумарних витрат на зазначені виробничі процеси, а також систему обмежень, що виключають некоректні рішення. Метод оптимізації дозволяє управляти параметрами буропідривних робіт на кожному етапі відпрацювання родовища скельних корисних копалин.

Ключові слова: : кар'єр, екскаватор, продуктивність, гранулометричний склад, гірнича маса, метод оптимізачії

\section{Математическая модель оптимизации буровзрывных работ при открытой разработке месторождений скальных полезных ископаемых}

\section{П. Щербаков, С. Тимченко, М. Битимбаев, Н. Сарыбаев, С. Молдабаев}

Цель. Определение функции приведенных затрат на буровзрывные, погрузочно-транспортные работы и механическое дробление в зависимости от стоимости машино-смены применяемого технического средства, режимов его эксплуатации, крепости взрываемых пород, стоимости применяемого взрывчатого вещества и качества дробления горной массы на основе разработанной математической модели оптимизации.

Методика. Применен метод статистической оценки естественной блочности скальной породы и качества ее дробления энергией взрыва. Выполнены статистические исследования основных показателей процесса механического дробления горной массы различной крупности и крепости составляющих ее кусков. С помощью специально разработанного образца экспериментального оборудования проведены выборочные исследования трещиноватости породы в процессе ее бурения шарошечным станком, что обеспечило репрезентативность выборки.

Результаты. Составлены статистические распределения блочности породы по длине каждой штанги с учетом ее положения в буровом ставе, а также по глубине скважины. Установлено визуальным сравнением экспериментальных и теоретических данных, что статистические распределения естественной блочности породы тесно коррелируют с гамма-распределением, дифференциальная функция которого имеет два положительных параметра. Установлена статистическая зависимость между результатами производства буровзрывных работ и суммарными затратами на добычу скальных полезных ископаемых.

Научная новизна. Введено понятие коэффициента дробления негабарита и получена его статистическая зависимость от крепости разрабатываемой породы и удельного расхода применяемого взрывчатого вещества. Предложен вариант изменения параметров дифференциальной функции принятого гамма-распределения применительно к прогнозируемому гранулометрическому составу горной массы.

Практическая значимость. Составлена экономико-математическая модель, включающая целевую функцию суммарных затрат на указанные производственные процессы, а также систему ограничений, исключающие некорректные решения. Метод оптимизации позволяет управлять параметрами буровзрывных работ на каждом этапе отработки месторождения скального полезного ископаемого.

Ключевые слова: карьер, экскаватор, производительность, гранулометрический состав, горная масса 